ISSN: 2599-3496 print

ISSN: 2614-2376 online

\title{
How does COVID-19 Impact Oil Palm Management Practices in Indonesia?
}

\author{
Ratnawati Nurkhoiry, Sachnaz Desta Oktarina* \\ Socio Techno Economy Research Group, Indonesian Oil Palm Research Institute
}

\begin{abstract}
Disrupted economy due to COVID-19 pandemic has been spilled to multifaceted sectors. Agriculture, more specifically oil palm sector was also hit by the impact of the catastrophe. This study is aimed to decipher the effect of COVID-19 pandemic to the management of oil palm plantation. The pandemic has caused the mobility and morbidity of people in such a way that exacerbated distribution of input factor, harvesting process, and transporting activities. Through online survey to 59 farmers consist of smallholder, government, and private estates, the study indicated that there was salient change of limiting activities particularly during immature and mature stages. Hence, the production of fresh fruit bunch (FFB) also decreased by $15 \%$ compared to business as usual as measured on monthly bases. Although the magnitude of production change was not statistically significance, planters still suffered from declining FFB farm gate price. On average, they received $5 \%$ lower selling price of FFB as a consequence of contracted CPO demand from prominent importing countries such as China, India, and Italy. The lower selling farm gate price has caused the income shocks to the farmers. Thus, quite large number of them experienced either turn-over or cost efficiency at the expense of fertilizer input. It is perpetuating the vicious cycle of lower smallholder attainable FFB yield. For a group that is at the high risk of infections as well, this circumstances has bring about concerns to Indonesian palm oil development, especially in terms of replanting realization and biodiesel blending progress in the long run.
\end{abstract}

Keywords: fertilizer, maintenance, pandemic, plantation, price

\section{INTRODUCTION}

COVID-19 outbreak definitely affected humankind around the globe. Indonesia as the fourth most populous country was one of highly impacted nation that prone to virus contraction (Djalante et al. 2020). The disruptive economy caused by the viral diseases has hampered the country's food sectors (Amanta and Aprilianti
2020). They projected that Indonesian employment in agriculture and domestic agricultural supply would be contracted by respectively $4.87 \%$ and $6.2 \%$. In terms of GDP, agriculture contribution to GDP would bearish for about $2.70 \%$ under the amplified global pandemic scenario (Maliszewska et al. 2020). Utilizing more comprehend scenarios, by incorporating the plausibility that even when the viral infec-

${ }^{*}$ Corresponding author:

Email: sachnazdes@gmail.com 
tion can be contained, McKibbin and Fernando (2020) simulated that the zoonosis disease would severely affect developing countries where health care system was underprivileged and population density was congested.

As populous country, Indonesia should take cautions of the uncertainty of the outbreak too since it was predicted that the volatility of the predictions of theoretical ending dates of pandemic in the archipelago is high. Holding the assumption that the virus evolves naturally, it means that there will be a radical change in the real-world scenarios that presumably taking place. it was recorded there will be around 170 days discrepancy of prediction days and scored 15 days volatility for Indonesia (Luo 2020). Nevertheless, for country which had robust infrastructure and massive advantages in terms of natural endowment, the circumstance would not be jeopardized (Brewin 2020). On the other hand, even though Indonesia was bestowed by oil palm as its natural endowment, it is still challenged by financing for biodiesel and PSR (Peremajaan Sawit Rakyat) replanting. The case may lead to a wicked problem especially when it comes to the sovereignty of the vulnerable groups and strategic goods, that are oil palm growers.

The farmers, especially smallholders were also at high risk for income shock due to pandemic. Researchers from IFPRI (International Food Policy Research Institutes) predicted that in the short run the largest effect of COVID-19 would be around the farm household difficulties in accessing labor input. Furthermore, the input supply would be uncertain due to delays, border closures, or difficulties in circulating goods across value chain (Boughton et al. 2020). The labor supply was also diminished due to three incidents that were; mortality and morbidity due to infection, and morbidity of caretaking the infected family members (McKibbin and Fernando 2020).

Despite there are ample existing body of literatures that simulated the macroeconomic impact of the pandemic, research in terms of real sector directly focused on impact of COVID-19 to the individual farmer is still way limited. Therefore, the purpose of the study is to untangle the potential changes in palm oil management due to the outbreak among smallholder and big estates. It investigated to what extent the farmers/planters changed their management practice during immature, mature, harvesting, and transporting stages as well as the discrepancy in terms of fresh fruit bunch (fFB) price and production in the short run. The scope of this research is not extending to oil palm management in the long-run as well as deep through explanation of scheme or non-scheme smallholders. Even so, this study is still fruitful as a prescription for the thinktank so that the authority may take informed decision in attempt to combat spread of the disease and to ensure the oil palm development.

\section{Materials and Methods}

The Indonesian oil palm development should be heavily focused on smallholder development since it was accounted for more than $40 \%$ of oil palm land cover. It was suspected that they will suffer the most in times of disruptive pandemic shock. In order to estimate the notion, this study has carried out online questionnaires to capture what is exactly happening in smallholder sector and how much it differs from the estates's management practices. Thus the online survey was circulated since 22 to 28 April 2020 to gain adequate respondents.

The samples were drawn using non-probability sampling of snowball sampling. The respondents were informed to 
fill the online questionnaires and were ask to distributed the questionnaire URL (https://bit.ly/CovidSawit) to the other farmers. The motivation of doing so was because at the moment of structuring the questions, Indonesia was implementing "social dan physical distancing" that not allowing people or a group of people to flock as a measure to counter against the viral transmission (Djalante et al. 2020). The URL circulated for a week has resulted in 59 respondents coming from $64.4 \%$ smallholders and $35.6 \%$ government/ private sector planters (that later to be called estates in this study).

The summary of the sample reasonably represented the whole population since most of the respondents were coming from respectively Riau, North Sumatera, Jambi, and Kalimantan Provinces (accounted for $22 \%, 20.3 \%, 18.6 \%$, and $13.6 \%$ each) where most of oil palm concessions were overlaid.

The respondents were administered questions revolved around oil palm cultivation practice during immature, mature, harvesting, and transporting stages, as well as how the planters perceived the discrepancy of production and price of FFB. The propensity of turn-over occurrence was also prompted prior and post the outbreak. The definition of each variables/questions were written in Table 1. The survey reliability was evaluated using Cronbach Alpha statistics, while the validity test was performed by executing Face/ Content Validity with the palm oil management experts from IOPRI/ Indonesian Oil Palm Research Institute (Bolarinwa 2015). The result of reliability test was displayed in Table 2.

The analysis of the processed data was performed by employing Exploratory Data Analysis (EDA) for the maintenance variables. For evaluation of the effect of COVID-19 to the changes in FFB price and production, T-student paired test was per- formed. However, the tool is only effective for parametric/ normally distributed data. Subsequently, the diagnostic checking of normality for continues variables (FFB price and production) was performed by Saphiro Wilk Test (Laake and Fagerland 2015; Sheard 2018). The null hypothesis for the test is: "the data was distributed normally". In the case of normality assumption violation/ non-parametric data, the Wilcoxon Sign Rank Test was operated to indicate the significant differences of paired observation evaluated prior and post the incident. Thus, it was specifically used to evaluate the discrepancy of preand post- COVID-19 outbreak FFB production and price in the farm gate level. The null hypothesis of the test is: "there is no significant difference of FFB price or production before and after the event of interest (COVID-19 outbreak)".

\section{RESULT AND DISCUSSION}

The Novel Coronavirus Disease or ubiquitously known as COVID-19 has hampered the global economy in the multifaceted ways (Maliszewska et al. 2020). The epidemiologic shocks has been spilled over to agricultural commodity as it impeded the transmission or flow of goods. McKibbin and Fernando (2020) assumed that the drivers of the labor shock was coming from mobility and morbidity of the farm workers. Oil palm growers inevitably might be suffered from these circumstances. Survey incorporated oil palm planters in the archipelago suggested that there were shift in best management practice that has been performed in the field. The profile of the overall respondents was summarized in Table 3.

\section{COVID-19 Impact to Immature and ma- ture Plant Maintenance}

During immature stage, the young palms need to be treated in such a way 
Table 1 Variable definition and metadata administered to the respondent

\begin{tabular}{|c|c|c|c|c|}
\hline No & Variable & Type & Value/ Unit & Definition/ Question \\
\hline 1 & Timestamp & interval & date \& time & $\begin{array}{l}\text { The time when respondent has finish submiting the } \\
\text { form }\end{array}$ \\
\hline \multirow{2}{*}{2} & \multirow{2}{*}{ Sector } & \multirow{2}{*}{ ordinal } & Estates & \multirow{2}{*}{ holding type that the planters is working } \\
\hline & & & Smallholder & \\
\hline 3 & Company & nominal & \multirow{4}{*}{ text } & $\begin{array}{l}\text { Name of the plantations if the holding type is an } \\
\text { estate }\end{array}$ \\
\hline 4 & Position & nominal & & Position at job (particularly filled by estate growers) \\
\hline 5 & Prov & nominal & & Province \\
\hline 6 & District & nominal & & District \\
\hline 7 & Work Experience (year) & ratio & year & $\begin{array}{l}\text { How long the respondent has been working on the } \\
\text { growing oil palms }\end{array}$ \\
\hline 8 & IM_LCC_Planting & nominal & \multirow{20}{*}{$\begin{array}{l}\text { pre-/post- } \\
\text { oubreak }\end{array}$} & $\begin{array}{l}\text { Are these Immature Oil Palm Managements exist: } \\
\text { Legume Cover Crop Planting }\end{array}$ \\
\hline 9 & IM_Supplant_Planting & nominal & & $\begin{array}{l}\text { Are these Immature Oil Palm Managements exist: } \\
\text { Supplant Palm Planting }\end{array}$ \\
\hline 10 & IM_Weed_Control & nominal & & $\begin{array}{l}\text { Are these Immature Oil Palm Managements exist: } \\
\text { Weed Control Maintenance }\end{array}$ \\
\hline 11 & IM_LCC_Maintenance & nominal & & $\begin{array}{l}\text { Are these Immature Oil Palm Managements exist: } \\
\text { Legume Cover Crop Maintenance }\end{array}$ \\
\hline 12 & IM_Ablation & nominal & & $\begin{array}{l}\text { Are these Immature Oil Palm Managements exist: } \\
\text { Ablation (young fruits removal) }\end{array}$ \\
\hline 13 & IM_Fertilizer & nominal & & $\begin{array}{l}\text { Are these Immature Oil Palm Managements exist: } \\
\text { Fertilizer Application }\end{array}$ \\
\hline 14 & IM_Pest_Disease_Control & nominal & & $\begin{array}{l}\text { Are these Immature Oil Palm Managements exist: } \\
\text { Palm Pest and Disease Control }\end{array}$ \\
\hline 15 & IM_Prunning & nominal & & $\begin{array}{l}\text { Are these Immature Oil Palm Managements exist: } \\
\text { Young Palms fronds prunning }\end{array}$ \\
\hline 16 & IM_Labor_Input_Price_Increase & nominal & & $\begin{array}{l}\text { Are these Immature Oil Palm Managements exist: Is } \\
\text { there any increase in input labor price? }\end{array}$ \\
\hline 17 & M_Weed_Control & nominal & & $\begin{array}{l}\text { Are these Mature Oil Palm Managements exist: Weed } \\
\text { Control Management }\end{array}$ \\
\hline 18 & M_Fertilizer_Use & nominal & & $\begin{array}{l}\text { Are these Mature Oil Palm Managements exist: } \\
\text { Fertilizer Application }\end{array}$ \\
\hline 19 & M_Pest_Disease_Control & nominal & & $\begin{array}{l}\text { Are these Mature Oil Palm Managements exist: Pest } \\
\text { and Disease Control }\end{array}$ \\
\hline 20 & M_Ditch_Road_Maintenance & nominal & & $\begin{array}{l}\text { Are these Mature Oil Palm Managements exist: Ditch } \\
\text { Road/ Drainage Maintenance }\end{array}$ \\
\hline 21 & M_Prunning & nominal & & $\begin{array}{l}\text { Are these Mature Oil Palm Managements exist: } \\
\text { Mature Palm Fronds Prunning }\end{array}$ \\
\hline 22 & M_Weed_Circle_Management & nominal & & $\begin{array}{l}\text { Are these Mature Oil Palm Managements exist: Weed } \\
\text { Circle Management }\end{array}$ \\
\hline 23 & M_Fertilizer_Availability & & & $\begin{array}{l}\text { Are these Mature Oil Palm Managements exist: } \\
\text { Fertilizer Availability }\end{array}$ \\
\hline 24 & M_Chemical Availability & & & $\begin{array}{l}\text { Are these Mature Oil Palm Managements exist: } \\
\text { Chemical Availability }\end{array}$ \\
\hline 25 & M_Labor_Input_Price_Increase & & & $\begin{array}{l}\text { Are these Mature Oil Palm Managements exist: Is } \\
\text { there any increase in input labor price? }\end{array}$ \\
\hline 26 & H_FFB_Harvesting & & & $\begin{array}{l}\text { Are these Oil Palm Harvesting Managements exist: } \\
\text { Fresh Fruit Bunch Harvesting? }\end{array}$ \\
\hline 27 & H_Midrib_Cutting & & & $\begin{array}{l}\text { Are these Oil Palm Harvesting Managements exist: } \\
\text { Oil Palm's Midrib Cutting? }\end{array}$ \\
\hline
\end{tabular}




\begin{tabular}{|c|c|c|c|c|}
\hline 28 & H_Transporting & nominal & & $\begin{array}{l}\text { Are these Oil Palm Harvesting Managements } \\
\text { exist: Fresh Fruit Bunch Transported to } \\
\text { Roadside Collection Points? }\end{array}$ \\
\hline 29 & H_Detached_Fruits & nominal & & $\begin{array}{l}\text { Are these Oil Palm Harvesting Managements } \\
\text { exist: Detached Ripe Fruits Collection? }\end{array}$ \\
\hline 30 & H_Harvest_Interval 8/7 & nominal & & $\begin{array}{l}\text { Are these Oil Palm Harvesting Managements } \\
\text { exist: Harvest Interval 8/7? }\end{array}$ \\
\hline 31 & H_Harvest_Interval 5/7 & nominal & & $\begin{array}{l}\text { Are these Oil Palm Harvesting Managements } \\
\text { exist: Harvest Interval 5/7? }\end{array}$ \\
\hline 32 & H_Harvest_Interval 15/15 & nominal & & $\begin{array}{l}\text { Are these Oil Palm Harvesting Managements } \\
\text { exist: Harvest Interval 15/15? }\end{array}$ \\
\hline 33 & H_Labor_Input_Price_Increase & nominal & $\begin{array}{l}\text { pre-/post- } \\
\text { oubreak }\end{array}$ & $\begin{array}{l}\text { Are these Oil Palm Harvesting Managements } \\
\text { exist: Harvesting Labor Input Price Increase? }\end{array}$ \\
\hline 34 & T_Transporting & nominal & & $\begin{array}{l}\text { Are these Oil Palm Transporting Management } \\
\text { exist: FFB transported from Roadside } \\
\text { Collection Points to Oil Palm Mill? }\end{array}$ \\
\hline 35 & T_FFB_Loading_Ramp & nominal & & $\begin{array}{l}\text { Are these Oil Palm Transporting Management } \\
\text { exist: FFB arrived in Loading Ramp? }\end{array}$ \\
\hline 36 & T_FFB_Roadside_Collection_Points & nominal & & $\begin{array}{l}\text { Are these Oil Palm Transporting Management } \\
\text { exist: FFB weighted in Roadside Collection } \\
\text { Points? }\end{array}$ \\
\hline 37 & T_Labor_Input_Price_Increase & nominal & & $\begin{array}{l}\text { Are these Oil Palm Transporting Management } \\
\text { exist: Transporting Labor Input Price } \\
\text { Increase? }\end{array}$ \\
\hline 38 & FFB_production(t-1) & ratio & \multirow{3}{*}{$\begin{array}{l}\text { MT/ ha/ } \\
\text { month }\end{array}$} & $\begin{array}{l}\text { How much the Fresh Fruit Bunch production } \\
\text { before the COVID- } 19 \text { outbreak? }\end{array}$ \\
\hline 39 & FFB_production(t) & ratio & & $\begin{array}{l}\text { How much the Fresh Fruit Bunch production } \\
\text { after the COVID-19 outbreak? }\end{array}$ \\
\hline 40 & Delta_FFBprod & ratio & & How much the FFB Production discrepancy? \\
\hline 41 & FFB_price(t-1) & ratio & \multirow{3}{*}{$\mathrm{Rp} / \mathrm{kg}$} & $\begin{array}{l}\text { How much the FFB farm get price prior to the } \\
\text { COVID- } 19 \text { outbreak? }\end{array}$ \\
\hline 42 & FFB_price(t) & ratio & & $\begin{array}{l}\text { How much the FFB farm get price post the } \\
\text { COVID-19 outbreak? }\end{array}$ \\
\hline 43 & Delta_price & ratio & & How much the FFB price discrepancy? \\
\hline 44 & Turn_over & nominal & $\begin{array}{l}\text { pre- / post } \\
\text { oubreak }\end{array}$ & $\begin{array}{l}\text { Do you experience turn-over (frequent } \\
\text { changing employee) in your company? }\end{array}$ \\
\hline \multirow{3}{*}{45} & \multirow{3}{*}{ Cost_Efficiency } & \multirow{3}{*}{ nominal } & Fertilizer Cost & \multirow{3}{*}{$\begin{array}{l}\text { In times of pandemic which cost do you } \\
\text { minimize the most? }\end{array}$} \\
\hline & & & $\begin{array}{l}\text { Maintenance } \\
\text { Cost }\end{array}$ & \\
\hline & & & $\begin{array}{l}\text { Harvesting } \\
\text { Cost }\end{array}$ & \\
\hline
\end{tabular}

that they can develop their vegetative growth to be ready to produce fruits. Among the best management practice during the immature stages, there were fertilizer use, supplant palms plantings, and legume cover crops (LCC) plantings that had visually significant different in prior and post the outbreak. As seen in Figure 1, the smallholders were claimed to reduce the fertilizer use the most when it comes to limited input availability. The discrepancy was measured about $44 \%$,
$50 \%$, and $66.67 \%$ difference for each activity. Due to income shock, they also consistently curtailed their activity in all maintenances of the immature stage as well as in weed control, LCC maintenance, pest and disease control, ablation, and immature plant pruning activity even in delicate changes. During the stage, there was no increase price of labor indicated that labor scarcity was not as severe as it seemed. Instead, many could provide to work due to loss in job from city that forced them to 
transmigrate, thus led to changes in rural labor market.

Table 2. Reliability Test (Cronbach Alpha) of Measurement

\begin{tabular}{lcc}
\hline $\begin{array}{l}\text { Management/ } \\
\text { Operation }\end{array}$ & $\begin{array}{c}\text { Cronbach } \\
\text { Alpha }\end{array}$ & $\begin{array}{c}\text { Standard } \\
\text { Deviation }\end{array}$ \\
\hline \hline Immature Plant & 0.92 & 0.03 \\
Mature Plant & 0.83 & 0.06 \\
Harvesting & 0.74 & 0.10 \\
Transporting & 0.60 & 0.16 \\
Source: primary data (processed by authors)
\end{tabular}

Table 3. Summary statistics of the responses

\begin{tabular}{llc}
\hline Variabel & Composition & (\%) \\
\hline \hline Sector & Smallholder & 64.41 \\
& Estates $^{*}$ & 35.59 \\
\hline Province & Riau & 22.03 \\
& North Sumatera & 20.34 \\
& Jambi & 18.64 \\
& Kalimantan ${ }^{* *}$ & 13.56 \\
& Aceh & 8.47 \\
& West Sumatera & 8.47 \\
& South Sumatera & 3.39 \\
& Bengkulu & 1.69 \\
& Jakarta & 1.69 \\
& Bangka Belitung Islands & 1.69 \\
\hline Work Experience & $<10$ years & 30.51 \\
& 10-20 years & 42.37 \\
& 21-30 years & 23.73 \\
Province & 30 years & 3.39 \\
Source: primary data (processed by authors) & \\
* denotes big estates owned by government & and private \\
** a composite of West, South, Central and East Kalimantan & \\
& & \\
& &
\end{tabular}

After three years, the oil palm usually graduates immature stage and start the mature stage that produce the fresh fruit bunch (FFB) for the first time. Generally, management practice conducted during this stage are not quite different, except for chemical use, ditch road maintenance, and circle weed management. In the course of pandemic, the stark changes occurred during mature stage was the scarcity of fertilizer and chemical in the market. Figure 2 captured the insight that the smallholder faced difficulties to access fertilizer and chemical the most compared to the estates. Some of them perceived $44.87 \%$ and $44.44 \%$ lower propensity to find the fertilizer and chemical respectively. This resonated the postulate that the implementation of social and physical distancing would impede the flow of goods and production factors (Boughton et al. 2020). Along with that, the income shock faced by the growers visually significant in limiting all maintenance during the oil palm most fertile stage.

\section{COVID-19 Impact to Harvesting and Transporting FFB}

Figure 3 portrayed oil palm harvesting activity that occurred before and after the outbreak. The following chart, Figure 4 displayed its transporting activities. Both of the works did not show much difference due to the outbreak compared to the maintenance on farm. This because farmer has come to the almost end of hardship in growing the plant and the expectation over selling the fruit and receiving income. When they had little money, they will definitely spend it to the most end of the value chain. There was not much prominent change during the pandemic, except for the midrib cutting. The harvest interval was slightly change for the estates from shorter $5 / 7$ to the longer of $8 / 7$ and $15 / 15$. Corley and Tinker (2016) suggested that the harvest interval must be reasonably short, or else there would be many overripe bunches with large numbers of detached fruits end up being overlooked.

Transporting FFB activities were started from carrying and weighting the fruits in the roadside collection points $(\mathrm{TPH}$, Tempat Pengumpulan Hasil). They were stacked by the harvesters, before being hoisted into the collection lorry to be subsequently loaded to the palm oil mill's 


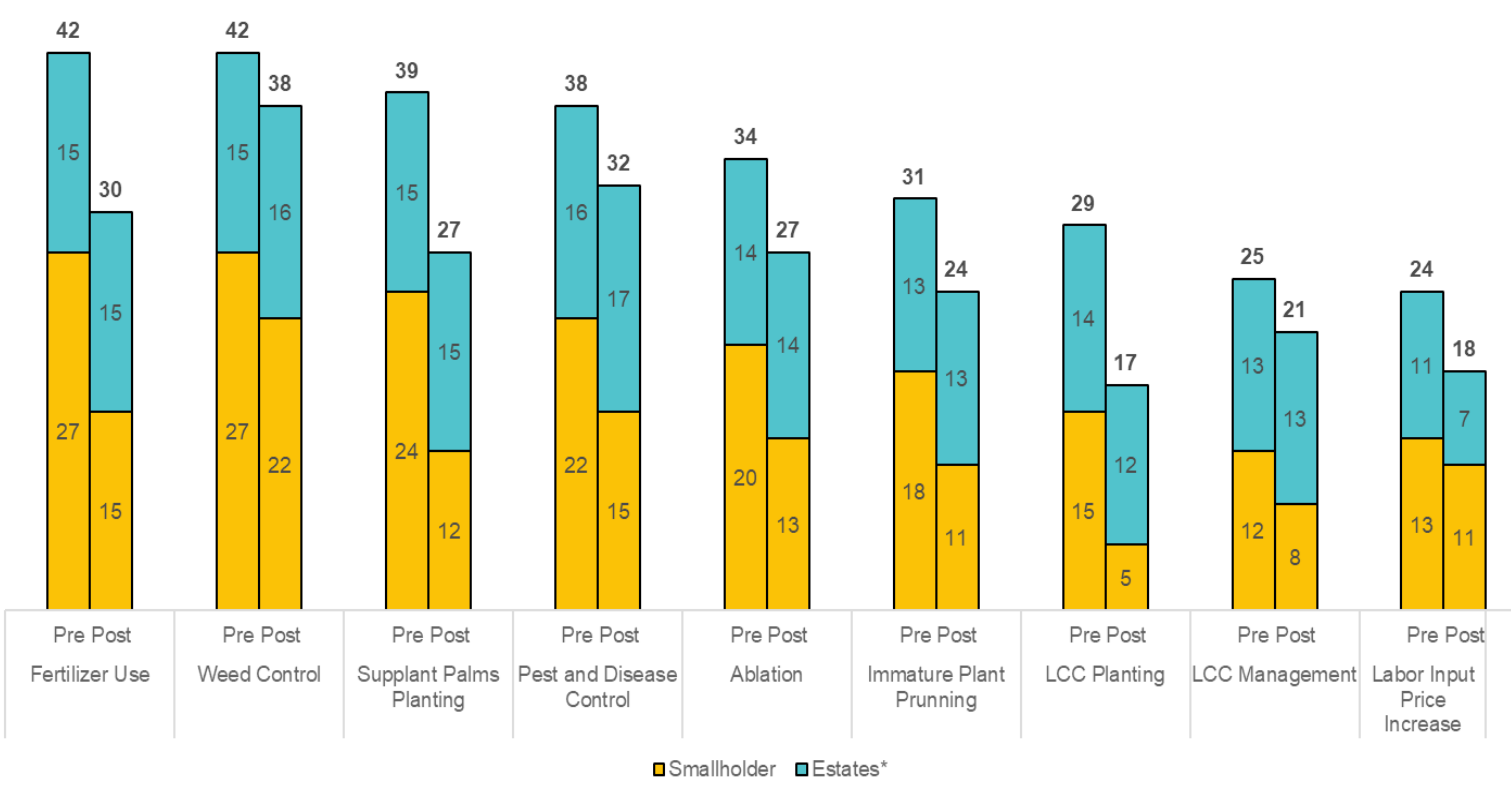

Figure 1. Envisage of oil palm management of immature plant due to COVID-19 Source: primary data (processed by authors)

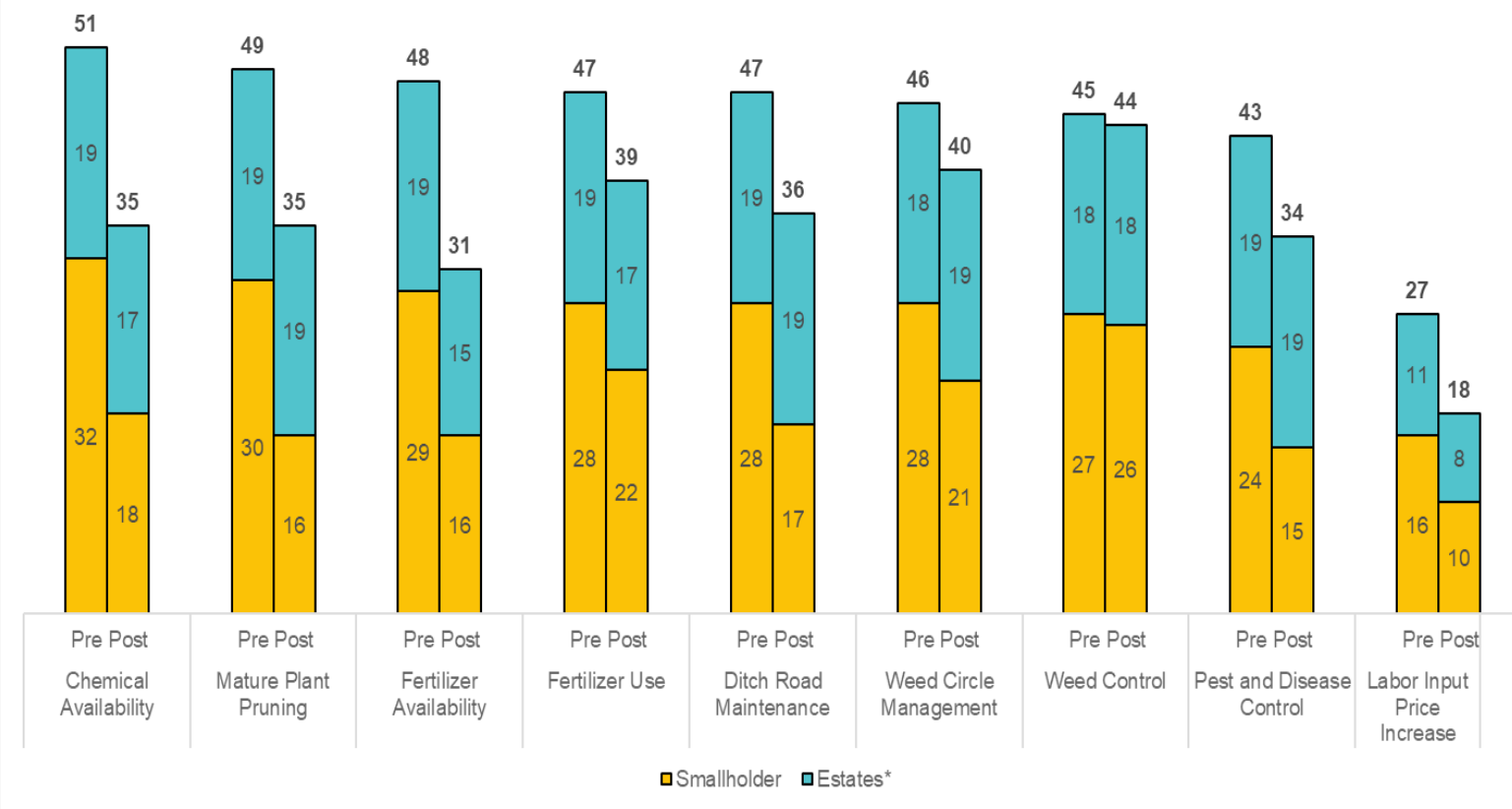

Figure 2. Envisage of oil palm management of mature plant due to COVID-19 Source: primary data (processed by authors)

loading ramp. Given the unprecedented income shock, the smallholder still found it difficult even in transporting FFB compared to that of the estates.

\section{COVID-19 Impact to the Planters Econ- omy}

Given the planters did not follow good management practice in the field, one should anticipate lower productivity of the 
oil palm. For example, when the young palms were not maintained by planting legume cover crop (LCC), it would affect soil fertility since the LCC would play to help nitrogen fixation and maintain soil humidity (Corley and Tinker 2016). If one did not comply with this rule, he/she would expect that the attainable yield would not reach its potential. Pruning also functioned pivotal role in maintaining the palm to allow ripening of the bunch next to it. It became visually easier to observed upcoming ripe bunch so that it would be harvested in the right time. The subsequent decay of the leaves could act as part of inner nutrient and carbon cycle surround the palm. The consequence of not doing so, would lead to erroneous in picking the unripe bunch that caused lowering oil extraction rate (OER), thus decreasing CPO yield in turn.

Furthermore, the circle and path of the palm was properly maintained for the sake of accessibility. Beside preventing young palms suffered from competitions, the circle also provided easier access for harvesting and detached fruits collections. It generated labor efficiency thus minimizing cost of labor. Even though one could minimizing the cost by appropriately maintained the circle, the portion of cost that bear the highest burden was still the fertilizer post. Hence, smallholder normally maximizing their profit at the expense of budget allocated for fertilizing the plant. Precisely, one might refer to Table 4 where more than $27 \%$ of smallholder would cut their fertilizer cost amidst unprecedented pandemic. Normally, the fertilizer is the highest cost amounted to about one-third of the total maintenance cost (Corley and Tinker 2016).

It was worth noting to investigate the production performance subjected to such incompliance. Apparently FFB production decreased on average from 2.13 $\mathrm{MT} \mathrm{ha}^{-1}$ month $^{-1}$ to $1.80 \mathrm{MT}^{\text {ha-1 }}$ month $^{-1}$. Surely, this magnitude might not be arbitrarily represented to the real population. The $15 \%$ decrease in production were deemed to be significant when it satisfied the mean difference test provided by either T-student paired test or Wilcoxon signed rank test for the nonparametric approach. After conducting Saphiro-Wilk Normality Test, it was indicated that diagnostic checking for normality test was rejecting null hypothe-

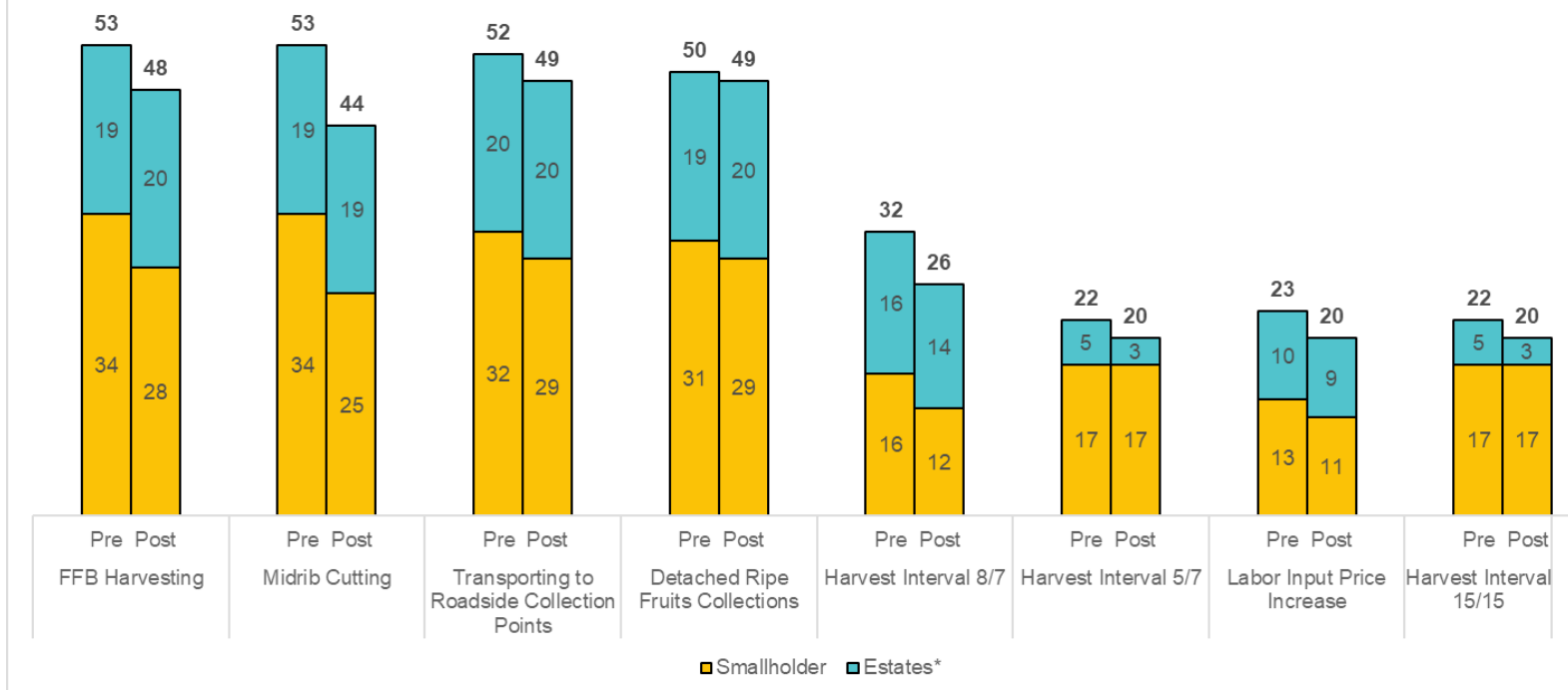

Figure 3. Envisage of oil palm harvesting activities due to COVID-19

Source: primary data (processed by authors) 


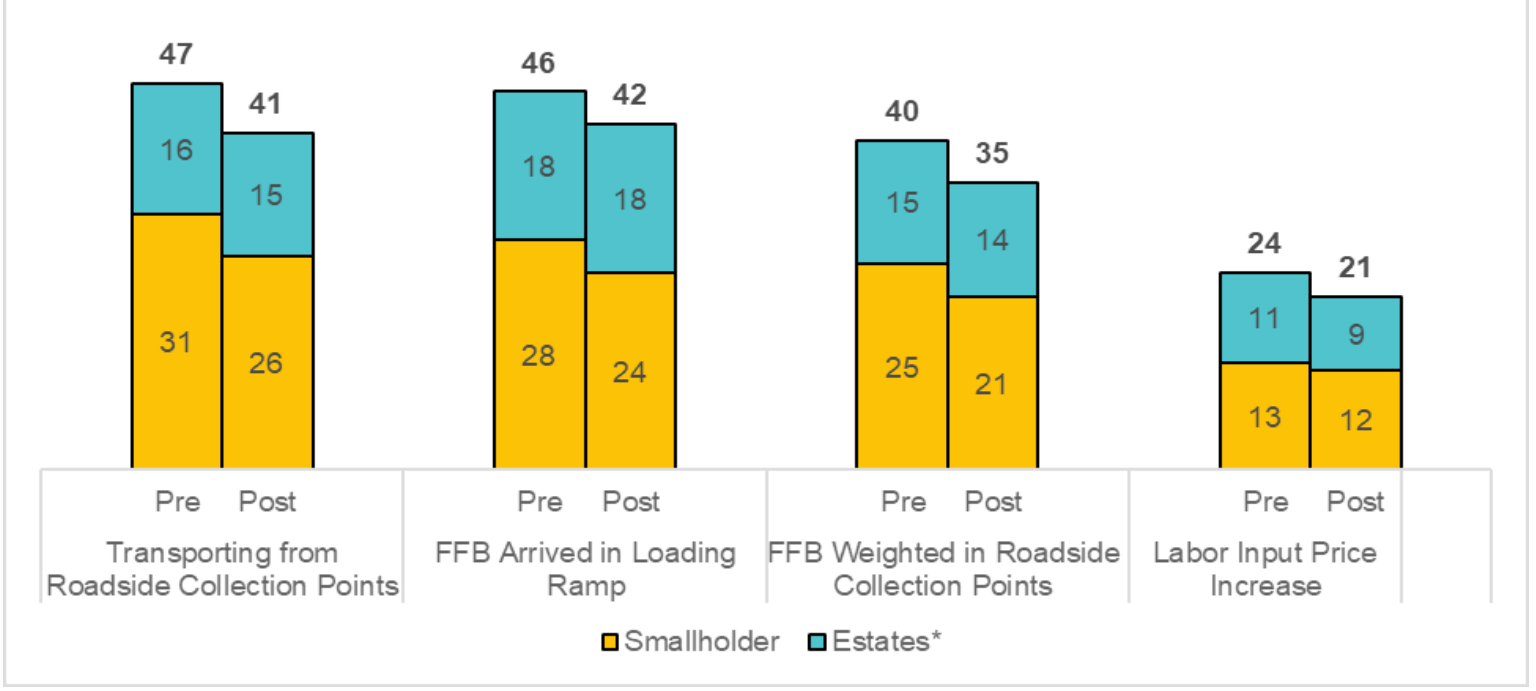

Figure 4. Envisage of palm oil FFB transporting due to COVID-19 Source: primary data (processed by authors)

Table 4. Contingency table of the responses

\begin{tabular}{lcc}
\hline Turn-over: & Smallholder (\%) & Estates* (\%) \\
\cline { 2 - 3 } Pre-outbreak & 51.85 & 48.15 \\
Post-outbreak & 42.86 & 57.14 \\
\hline Cost Efficiency: & & \\
Harvesting & 3.39 & 1.69 \\
Maintenance & 23.73 & 10.17 \\
Fertilizer & 27.12 & 10.17
\end{tabular}

sis which meant the observations did not follow normal distribution (W0 $=0.501$, $\mathrm{W} 1=0.55, \mathrm{p}$-value $<\alpha=1 \%$ ) (Sheard 2018). Therefore, it eventually proceeds to the non-parametric Wilcoxon signed rank test (Laake and Fagerland 2015). The Wilcoxon statistics obtained was 348 ( $p$-value $>\alpha=1 \%)$. With smaller and insignificant statistics, it was difficult to say that the median and mean of change in production was not zero.

The insignificancy of FFB production might be due to the effect of the mismanagement that can be physically observed after 6 months upon completion. Unlike FFB price, it did not directly result in tangible outcome. The FFB price transmission had interlinkage to the global market. The FFB farm gate price heavily affected by any dynamics or changing sentiments in the major trading countries. The pandemic has disrupted the economy of Indonesian oil palm trading partners. Among them were China, Italy, Netherland, and India that had been contracted by the COVID19 pandemic. The withering condition of the outbreak has stipulated the decrease of growth for corresponding economy for about $0.4 \%$ to $6.2 \%, 0.2 \%$ to $8.3 \%, 0.2 \%$ to $8.4 \%$, and $0.2 \%$ to $4.93 \%$ respectively (Maliszewska et al. 2020; McKibbin and Fernando 2020). In fact, for India and Italy case, the volatility of pandemic ending day prediction were higher than that of Indonesia. Meanwhile, The Netherland was benefited as having lower volatility magnitude among those countries (Luo 2020).

For China itself, Abiad et al. (2020) has simulated that the economy would face those that happened in the 2003 when SARS epidemic existed. It projected to have a sharp and temporary drop consumption sector. The health shock definitely has lower down the countries purchasing power by investing more on health and saving more money as antici- 
pating measures (Brewin 2020). The act of tighten the purse that conducted simultaneously by those countries has obscured the price transmission that received by the FFB growers in the short run. Our result suggested that on average the farmer received lower selling price from Rp $1449 \mathrm{~kg}^{-1}$ to Rp $1382 \mathrm{~kg}^{-1}$ or $5 \%$ decrease of post to prior the outbreak. The mean changes were diagnosed by Saphiro-Wilk Normality Test as well and it conveyed that the observations follow normal distribution (W0 $=0.98, \mathrm{~W} 1=0.95, \mathrm{p}$-value $>\alpha$ $=1 \%)$. T-student paired test has resulted significant $\mathrm{t}$ statistics $(\mathrm{t}=3.1379, \mathrm{df}=58$, $p$-value $<\alpha=1 \%$ ) implying that the mean change was not equal zero.

Beside lower demand of CPO, Indonesia also experienced some challenges in its oil palm development particularly in regards of biodiesel blending realization. It was targeted to achieve at least $30 \%$ FAME (Fatty Acid Methyl Ester) in the 2025 as also supported by $73 \%$ of the public (Oktarina et al. 2019). However, it seems doubtful that the target become accomplished since the CPO fund needs to incentivize 100 USD per tonne CPO converted to biodiesel. In times when people all across the world minimize their expenditure, it seems highly unlikely that biodiesel production will meet the target. It was estimated that the world biodiesel production will decrease up to $2.01 \%$ (Oil World 2020).

\section{Potential Covid-19 Remedies in rela- tion to oil palm development}

The impact of not applying best management practice in oil palm plantation was predicted to lower the yield in the next six months. Thus, in the long run it will affect farmer allocation to the replanting as well (PSR, Peremajaan Sawit Rakyat). Furthermore, the simplification of PSR procedure also might give advantage by living allowance disbursement (JADUP, jatah hidup) as relief upon the farmers who are at high risk. Other forms of assistances are food stamp or direct cash transfer as a buffer to anticipate food price inflation that has been predicted by Amanta and Aprilianti (2020). Other than those mentioned above, growers might still generate income by make the most of its land for intercropping, especially by planting cash crops. Even though this approach was less desirable by the big estates, however, for the smaller holdings the intercropping application within the young palms was still economically beneficial during the gestation period. Another feasible way to pluri-activity is by utilizing oil palm biomass to diversify the income (Chin et al. 2016).

In the meantime, the income of grower will be varied by the bearish of CPO demand in global market. It will also exacerbate oil palm grower in terms of lowering FFB farm gate price. Global negative sentiment in CPO demand might be overcame by loosen up trade restriction. The government might negotiate and deal by relaxing some trade barriers for the prominent importing countries. Or else, the possibility to expand the market to other prospective buyers in the country who is not acutely affected by the pandemic is still promising too. Within domestic treatment, the policy maker needs also to improve availability and affordability of agricultural input. Lesson learned from neighboring country has suggested fertilizer cost subsidy application and redemption using e-money system (Boughton et al. 2020). Extra protection for supply chain actors with additional health measure is necessary as a safeguard to ensure the flow of goods. 


\section{CONCLUSION}

Oil palm was inevitably affected by the COVID-19 pandemic due to its role as an Indonesia's strategic commodity traded in the world. Moreover, the world's main consumers were most impacted by being the epicenter of the pandemic worldwide. With the limited supply of inputs, the operations of oil palm plantations have been hampered. There were severely limited maintenance activities in both immature and mature management. Moreover, many growers were unavoidably experiencing either turn-over or tighten the purse at the expense of the fertilizer cost. The income shock happened due to fallen FFB production and price. The circuit breakers besides virus containment are suggesting the government to save oil palm farmers particularly in the short run period. The government responses might be relaxing trade barrier, guaranteeing supply of input factors, stockpiling direct cash transfer or food stamp, and simplifying the PSR process.

\section{REFERENCES}

Abiad A, Arao M, Dagli S, Ferrarini B,Noy I, Osewe P, Pagaduan J, Park D, Platitas R. 2020. The economic impact of the COVID-19 outbreak on developing Asia. Manila (PH): Asian Development Bank (ADB).

Amanta F, Aprilianti I. 2020. Indonesian food trade policy during COVID-19. Jakarta (ID): Center for Indonesian Policy Studies (CIPS).

Bolarinwa O A. 2015. Principles and Methods of Validity and Reliability Testing of Questionnaires Used in Social and Health Science Researches. Nig. Postgrad. Med. J.

Boughton D, Goeb J, Lambrecht I, Mather D, Headey D. 2020. Strengthening smallholder agriculture is essential to defend food and nutrition security and rural livelihood in Myanmar against the COVID-19 threat: elements for proactive response. Yangon (MM): International Food Policy Research Institute (IFPRI).

Brewin D. 2020. The impact of COVID-19 on the grains and oilseeds sector. Can. $\mathrm{J}$ of Agric Econ.

Corley RHV, Tinker PB. 2016. The oil palm. 5th ed. United Kingdom: Wiley Blackwell.

Chin HC, Choong WW, Alwi SRW, Mohammed $\mathrm{AH}$. 2016. Using theory of planned behaviour to explore oil palm smallholder planters' intention to supply oil palm residues. J of Clean Prod.126: 428-439

Djalante R, Lassa J, Setiamarga D, Sudjatma $A$, Indrawan $M$, Haryanto $B$, Mahfud C, Sinapoy MS, Djalante S, Rafliana I, Gunawan LA, Surtiarti GAK, Warsilah H. 2020. Review and analysis of current responses to COVID-19 in Indonesia: period of January to March 2020. Prog in Disaster Sci. 6:100091.

Laake P, Fagerland MW. 2015. Statistical inference. In: Laake P, Benestad HB, Olsen BR, editors. Research in Medical and Biological Sciences. Academic Press: 2nd ed. p. 379-430. https:// doi.org/10.1016/B978-0-12-7999432.00011-2

Luo J. 2020. Predictive monitoring of COVID-19 [White paper]. Singapore University of Technology and Design: Data-Driven Innovation Lab.

Maliszewska M, Mattoo A, van der Mensbrugghe D. 2020. The potential impact of COVID-19 on GDP and trade. Washington DC: World Bank Group.

McKibbin W, Fernando R. 2020. The global macroeconomic impacts of COVID-19: seven scenarios. Center for Applied Macroeconomics Analysis (CAMA): CAMA Working Papers.

Oil World. 2020. Biodiesel: World Pro- 
duction, Feedstock Use, and Selected Data for Major Countries [Data file and code book]. Retrieved from OIL WORLD, https://www.oilworld.biz/t/ publications/data-base

Oktarina SD, Nurkhoiry R, Nasution MA, Rahutomo S. 2019. Riset pasar biodiesel B20 di Indonesia: Evaluasi terhadap Produk dan Kesadaran Konsumen. AKP. 17(2): p.79-93.

Sheard J. 2018. Quantitative data analysis. In: Williamson K, Johanson G. editors, Research methods. 2nd ed. p. 429-452. Chandos Publishing. https:// doi.org/10.1016/B978-0-08-1022207.00018-2. 